\title{
Modeling of the Process of Personnel Motivation for Innovation Activity
}

\author{
MYKHAYLO VOYNARENKO \\ First vice-rector, vice-rector for scientific- \\ pedagogical \\ Khmelnytsky National University \\ 11, Instytutska str. \\ UKRAINE
}

\author{
VIACHESLAV DZHEDZHULA \\ Department of Finances and Innovative \\ Management \\ Vinnytsia National Technical University \\ 95, Khmelnytsky highway \\ UKRAINE
}

\author{
IRYNA YEPIFANOVA \\ Department of Finances and Innovative Management \\ Vinnytsia National Technical University \\ 95, Khmelnytsky highway \\ UKRAINE
}

\begin{abstract}
The peculiarities of motivation formation of employees of industrial enterprises to innovation activity have been investigated. The approach to assessing employees' motivation to innovation activity with the use of the Harrington function has been offered. The concept of motivational acceleration of innovations and motivational inertia of innovations has been proposed. Motivational acceleration refers to the period of time in years during which the investment process which is carried out by motivated employees will soon go into the profitability zone compared to the process implemented by non-motivated employees. Motivational inertia of innovation is defined as an additional period of profit-making from the innovation process as compared to the process carried out by non-motivated employees.
\end{abstract}

Key-Words: - motivation, motivational acceleration, motivational inertia, the Harrington function, innovation activity

Received: October 7, 2019. Revised: May 3, 2020. Accepted: May 8, 2020. Published: May 18, 2020.

\section{Introduction}

Modern management in the context of globalization can only be effective if innovation is actively implemented. The introduction of innovation requires an awareness of the importance of the tasks and internal driving forces to accomplish them. The innovation process cannot be implemented in the situation when employees are not interested in its active implementation. The innovative strategies chosen for implementation require from the enterprise employees new actions, approaches, knowledge. The introduction of new technologies and approaches requires from the employee to leave the area of usual actions and perform unusual and not always clear new operations.

It is well-known that persistence in achieving goals is formed in employees only if there are strong motivational factors, and then with low motivation there is a performance of work that will not lead to punishment. Thus, the implementation of new qualitative and quantitative leaps in the development of the enterprise requires appropriate motivation of employees, the creation of a complex of motivators and penalties to achieve this goal.

That is why it is important to formulate a more efficient process of personnel motivation to innovation activity.

\section{Literature Review}

As it is stated by V.V. Stadnyk [1], the activation of innovative labor is the process of involving employees in the innovation activity by creating a system of internal incentives. Incentives should be permanent in nature, flexible, that is, they change depending on the change in employee preferences, include tangible and intangible (sociopsychological) components.

The notion of the essence of motivation in the 
scientific literature has been sufficiently covered; in particular, Bokovets V.V. [2] believes that motivation is the process or set of related managerial decisions on the formation of motives, actions of employees. A.A. Klymchuk, A.M. Mykhailov [3] contrast the concept of "motivation" to the concept of "stimulation" and conclude that the difference between them is the rating of "motivation" category to internal desires to do something, and "stimulation" cannot be done without external influence.

Researchers of peculiarities of people motivation Yerkes and Dodson [4] have shown that the best productivity comes from average motivation, but in conducting their research they used coercive motivation, which does not allow extending their conclusions to all possible cases of motivation.

The impact on a person by means of his needs was considered in works [5]-[10] of Maslow, Alderfer, McClelland, Herzberg, Mayo and others. A. Maslow [8] in his works developed a hierarchy of human needs and presented it in the form of a pyramid based on basic physiological needs, the need to be safe and love. The top of the pyramid is the need for self-actualization and aesthetics. D. McClelland [6] examines the human needs of higher levels; he proposes to divide all human needs into the need for achievement, complicity and power.

The concept of "motivation" in its evolution has passed certain historical stages - from the policy of "whip and gingerbread" (punishment and remuneration) to "the concept of human resources" (the perception of the employee as a key figures in production, on whom the final results of production activities depend) [11].

Modern science has a number of scientific theories that describe the impact of motivation on the employee. One of the most ancient is the theory of "penalties and rewards", which proposes the use of simple incentives in the form of rewards and punishments. This approach is the simplest one; it allows you to use human needs to achieve the goals set at the enterprise. But financial incentives have a certain limit of effectiveness due, on the one hand, to the level of human needs and ambitions, on the other hand, it is limited by fear and unwillingness to do the work in general.

To solve the problem of employee motivation, one must understand what psychological types of personality and generation they are. The peculiarities of motivation of employees belonging to different psych types have been widely considered in the scientific literature. In particular, D. McGregor [10] proposes to motivate employees in accordance with the theory "X", "Y", "Z". The first theory is based on the fact that the employee has no initiative and does not want to take responsibility. Such employees are the worst contributors to innovation; their motivation is possible through coercion and material encouragement. Employees belonging to group Y actively participate in the work of the enterprise and receive from their work not only material but also moral satisfaction. Under certain conditions, the employee is ready to take not only additional duties but also additional responsibilities. Theory $\mathrm{Z}$ describes the behavior of employees who wish to work in a group but are willing to take individual responsibility.

Professional motivation became the topic of the works of D. McGregor [10], V. Vroom [12]. In order to reduce the risk of professional motivation, some scientists offer to involve employees in the management of the enterprise and thus to form a complete picture of the ongoing processes. Awareness of the problems that arise in the enterprise, the problems and successes that arise in the course of the activity, allows employees to avoid problems related to injustice.

D. Carnegie wrote that stimulating an employee's personal desire for qualitative and timely accomplishment of tasks should be based on encouraging his or her own ambitions [13]. The main direction of stimulating the employee to do the job is the ability to convince the person in his or her own abilities, the ability to achieve the result while performing the work.

In the work [14]-[15], it is emphasized that highly educated human resource is a prerequisite for the organization that is learning and has a direct impact on organizational innovation. The authors [16]-[17] believe that resistance to innovation can act as a barrier to innovation activity, which can only be avoided by increasing organizational commitment. Innovative behavior of an employee is determined by both internal and external motivation [18].

The results of the survey [19] have shown that the problem areas in the organization of innovation activity are mainly the lack of motivation of employees to offer innovative ideas, other priorities of the enterprise and low budget for innovation.

In the work [20], it has been proposed to use modeling methodology of structural equations to evaluate employees' motivation for innovation. The authors have concluded that in order to increase employees' motivation to innovation activity, it is possible when they are rewarded and recognized, and if they are entrusted with authority, as their position in the organizational structure requires. The 
authors [21] have proposed a multilevel model that examines the effects of employee engagement climate on the individual-level process of linking employee regulatory focus (promotion and prevention) to innovation via thriving. In the work [22], a mathematical and structural model of the relationship between motivation forms from selfdetermination theory and the concept of personorganization (PO) is considered to provide insight into some of the factors that can influence high-tech R\&D employees' IWB.

To implement the modeling process, it is advisable to use the universal indicator - the Harrington function of desirability. According to [23] this function is a quantitative, unambiguous, unique and universal indicator of the quality of the object under study, it is characterized by such properties as adequacy, efficiency and statistical sensitivity, which allows you to use it as an optimization criterion. A number of researchers [24]-[27] has applied this approach, but it requires clarification and refinement of a set of influencing factors to assess the level of employee motivation to innovation activity.

\section{Research Methodology}

Effective motivation must cover motives and incentives. The motive refers to a specific internal need that drives an employee to take certain actions and deeds that can satisfy the need. Everyone has their own motivational preferences, which are determined by their social status, well-being, position and other factors.

Incentives, however, are external factors that underpin motives. Incentives for employees to innovation should be shaped by a set of different action plans aimed at increasing the interest in solving non-standard tasks, the tangible and intangible benefits received, and in the case of nonacceptance - the penalties. All employees of the enterprise should be encouraged. The owners of the organizations, who must take into account the dependence of managers' remuneration on the effectiveness and efficiency of their decisions and management actions in the incentive system, define the incentive conditions for senior management.

The study of various theories of personnel motivation by scientists at different times proves to be an indisputable fact - the development of the enterprise occurs under the conditions of personnel development, which is motivated to achieve the goal, facing the enterprise, whose needs are met by the use of appropriate forms and methods of stimulation.
The motivation policy of the enterprise, taking into account the acceptability of innovation by personnel, should include a system of both motivational factors and incentives. The purpose of motivation creation is to stimulate and support the behavioral activity of employees in the direction of innovation, which in turn leads to an increase in the profit of the enterprise because of their introduction in the activity of the enterprise. At the same time, the innovation at the enterprise can take a different form: from a new product to an innovative management decision, innovative methods of energy saving, new progressive methods of marketing products.

The importance of motivational policy can also be explained by the fact that it is human knowledge that is the origin and condition for innovation. There are two types of knowledge in the literature explicit and implicit [20]. Explicit knowledge is usually knowledge that is directly stored in a business database and is quite useful if it is used in a timely and effective manner. At its core, this type of knowledge is a business asset of an enterprise.

In addition, businesses have implicit knowledge that is created by human activity. The company itself can also influence the creation of implicit knowledge through the social environment. This makes the company unique and attractive to new employees. The main conditions that determine the formation of a social climate that leads to innovation development can be obtained under the following two conditions [21]:

- involvement of all employees in the development of innovative solutions and the creation of internal relationships between different departments;

- guarantee (from the management of the enterprise) that there is no need to worry about mistakes that could potentially be made in the process of testing a new decision.

Summarizing the above and considering the works of the authors [12], [16]-[22], [28]-[29] we can conclude that the motivation to innovation activity is a multifaceted long-term or short-term direct or indirect influence on the employees of the enterprise in order to form their conscious choice and change of the structure of value orientations aimed at the development of new skills, knowledge, desires in order to implement innovative strategies and get an additional profit for the enterprise. The ultimate goal of all actions aimed at motivating or demoting an employee is to increase the profit of the enterprise.

The most effective, in our opinion, is the organizational, intangible motivation, which is 
based on the peculiarities of the employee's perception in the society, stimulation of his ambitions or deep fears. It is intangible motivation that has a longer duration of action than tangible motivation, which risks coming to naught after the end of material incentives. But the intangiblemotivated employee is the most sensitive to management actions and social injustice in terms of rewards, stimulations, or changes in authority and position. A demotivated employee because of unfair management actions can cause much more harm to the enterprise than a financially motivated employee.

If the above statements are depicted graphically in the form of labor efficiency curves (Fig. 1), we can see that in the initial motivation (only tangible or intangible and intangible) - Curve 1 - the motivation of workers in a certain period reaches its saturation and begins to decline (point $S$ ).

Saturation point (p.S) of Yerkes and Dodson [4] characterizes the change in employee performance, so additional stimulation is required to maintain the required level of performance (Curve 2). This stimulation depends on the type of personality of the employee.

If the employee belongs to categories $\mathrm{Y}$ and $\mathrm{Z}$, it is desirable to maintain his / her motivation level comprehensively by satisfying his / her aspirations and ambitions and financially.

Such workers, after reaching the saturation point, need additional incentives in the form of intangible incentives, promotions, changes in working conditions or the nature of work. Employees of category $\mathrm{X}$ do not actively respond to moral incentives, so a more coercive and punitive policy is more effective for them. This category responds more strongly to feelings of fear than to feelings of moral satisfaction.

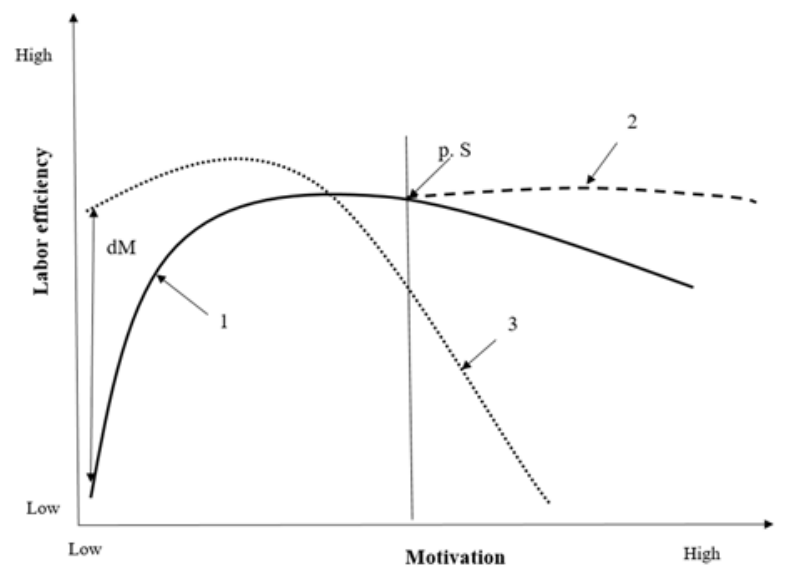

Figure 1: Dependence of labor efficiency on the level of employee motivation in the implementation of innovative strategies

A number of employees need no additional motivation and are active in innovation implementation. Such employees have the highest level of awareness and sense of the need for positive changes in the enterprise. Their level of initial motivation is high and such an employee can dramatically change their motivation and efficiency in the case of a sense of injustice, being invaluable on the part of management. Curve 3 describes this situation. The initial level of motivation for such workers is much higher than for the "ordinary" workers by $\mathrm{dM}$. Intangible motivation is essential for this type of employee, which helps to maintain the initial level of motivation at a constant level or to promote its growth. Such employees are not afraid of new approaches, changes in the enterprise, try to quickly master the innovations that are being introduced, motivate other workers by their example, especially from the stratum of those who are actively responding to intangible stimulation.

From the perspective of the duration of the innovation cycle, the impact of innovation is significant. Let us consider the innovation lifecycle curves with or without motivation (Fig. 2).

Curve 1 corresponds to the lifecycle of an innovation process carried out by non-motivated employees, Curve 2 corresponds to the lifecycle of an innovation process carried out by motivated workers. Motivated employees make it faster for the company to get profit, that is why the curve of innovation cycle 2 crosses the abscissa axis earlier and goes into the profit zone. Although at the investing stage some funds may be spent on personnel motivation, as it is evidenced by the lower position of Curve 2 relative to Curve 1 in the investment zone, but in the end, the innovation process 2 proceeds longer, better, and it allows getting more profit. The difference of the ordinates of the curves with the same abscissas gives us the value of the additional profit that the enterprise receives at the expense of employee motivation (segment 3).

To characterize these processes, it is offered to introduce two new concepts: motivational acceleration of innovation (MA) and motivational inertia of innovation (MI). Motivational acceleration will be the period of time in which an innovative process implemented by motivated workers will soon move into the profitability zone compared to the process implemented by non-motivated workers.

Figure 2 shows the period of motivational acceleration as the difference between the values of 
the arguments of Points 2 and 1 .

That is, motivational acceleration can be defined by the following formula:

$$
M \Pi=X_{2}-X_{1}
$$

where $X_{I}$ is the period of reaching the profitability zone by an innovative process carried out by non-motivated employees, years; $X_{2}$ is the period of reaching the profitability zone by an innovative process carried out by motivated employees, years.

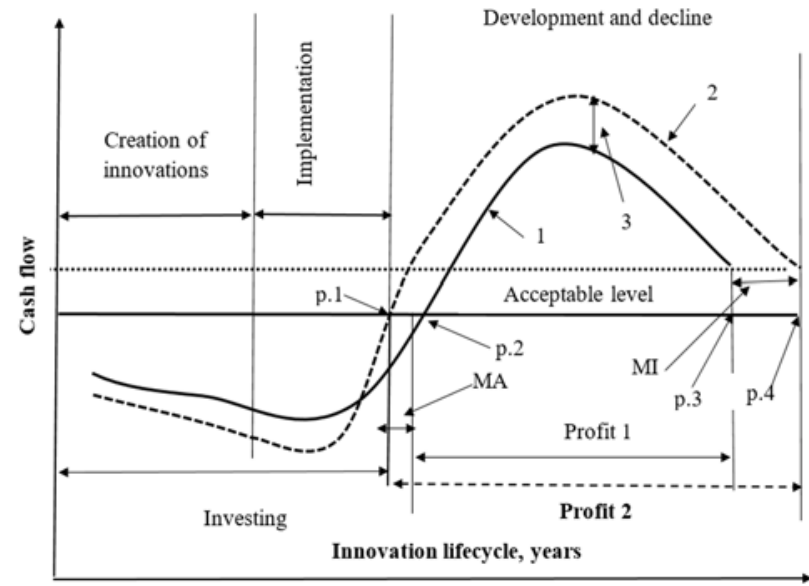

Figure 2: Innovation lifecycles with motivation and without motivation

Motivational inertia of innovation is defined as an additional period of profit making from the innovation process as compared to the process carried out by non-motivated employees.

In Fig. 2, the motivational inertia is shown by the zone of additional time of acceptable profit making. The length of this zone in terms of motivation is proportional to the level of employee motivation. Given that the innovation process is approaching its recession, investing in employee motivation may also approach zero. There is no need to invest in motivating employees to implement an irrelevant innovation project. In the general case, the length of the period of motivational inertia depends primarily on intangible motivation. The employees interested in moral incentives or for the sake of satisfying their own ambitions may for a long time invest their efforts in maintaining the process in an up-to-date state, i.e. with profitability above the acceptable level.

Motivational inertia is determined by the formula:

$$
M I=X_{4}-X_{3}
$$

where $X_{4}$ is the number of years corresponding to the development of the innovation process in the area of acceptable profitability (the process is carried out by motivated employees), years; $X_{3}$ is the number of years corresponding to the development of the innovation process in the area of acceptable profitability (the process is carried out by nonmotivated employees), years;

The value of excess profit $\partial \Pi$ of innovation process 2 over innovation process 1 gives us the total cumulative profit received by the enterprise additionally at the expense of employee motivation. Analytical determination of this excess can be determined as follows:

$$
\partial \Pi=\int_{m 1}^{m} f_{2}(x)-\int_{m 2}^{m} f_{1}(x)
$$

where $f_{2}(x)$ is the function of the development of an innovative process implemented by motivated employees; $f_{l}(x)$ is the function of the development of an innovative process implemented by nonmotivated employees; $x$ - years of process consideration in the profitability zone.

The difference of areas under the functions of development of innovation processes gives us the profit received at the expense of motivations. Similarly, to Curve 2 it is possible to construct a conditional curve that would characterize the flow of the innovation process in its implementation by non-motivated employees. It is obvious that the profitability period for this case would be the least from all considered.

The incentive system for innovation processes should include, on the one hand, components of ongoing incentives and, on the other hand, incentives based on the performance of the enterprise as a whole. This incentive approach will emphasize the importance of corporate culture as well as the importance of innovation activity not only for the enterprise as a whole, but also for each of its employees.

In turn, the incentive system must necessarily encourage the development of creativity of employees of the enterprise, which is a prerequisite for innovation creation.

It should be taken into consideration that the motivation of innovation activity, as opposed to the motivation of the activity as a whole, should take into account that in the initial stages of innovation activity it is difficult to assess the result of employees.

This is because employees need to be stimulated before the final product is received. It is especially 
difficult to evaluate the result in the case of new product development in the initial stages, since it is unknown exactly what result will be obtained.

The center of all actions is the employee who is directed by organizational and economic measures for motivation, creation of motives, incentives, values, bringing them to the employee, securing and maintaining them at the required level.

There are different ways of classifying motivational factors today. The main groups of motivational factors studied in many researches relating to motivation at management and employee level in the organization are the following:

- safety of work;

- personal loyalty of management to employees;

- interesting job;

- good working conditions;

- discipline that has a tactical form;

- high salary level;

- promotion opportunities in the organization;

- good evaluation of the work performed.

In general, motivational measures are divided into direct and indirect motivation. The motivation of direct action is related to the immediate achievement of the final result - the commercial benefits of innovation implementation and a direct impact on the employee. In most cases, the basis of the motivation of direct action is the proportion of the organization's additional profit from the innovation implementation that increases the employee's remuneration.

Material incentives of direct action that motivate an employee are the following: the size of wages; accidental benefits; bonuses; one-time rewards; benefits; insurance. In foreign countries, innovation activity is taken into account in remuneration and financial incentive systems, which is noticeable in the payment of royalties. Israel ranks first in the world in terms of funding employees for innovation technology - $4.3 \%$ of GDP, France - 3\%, the United States $-2.2 \%$. Each dollar invested in human capital is equivalent to $\$ 15$ from the export of knowledgeintensive and high-tech products made in the country. Israel receives \$13-14 billion annual profit due to innovative product sales. In Japan, the state returns $80 \%$ of the funds invested in workforce improvement projects. In Ukraine, similar expenditures for the next year are projected at just over $0.4 \%$ of GDP [30].

Enterprises can also use intangible incentives of direct action, in particular to promote the careers development of innovative workers.

The motivation of indirect action does not affect directly on the employee, but it creates a favorable environment for innovation activity and work of the employee, and it begins to influence on him.

The main material incentives that have an indirect impact on employees are usually such as payment of membership in scientific societies; payment for participation in scientific conferences; payment for participation in professional development programs in related fields; the right to entrepreneurship. In addition, in Western countries, such incentive indirect action as the acquisition of company shares is actively used.

Enterprises should also pay attention to a number of intangible, indirect impact incentives that motivate employees to innovation activity and help increase labor productivity and creativity, including:

- development of professionalism of all employees of the enterprise;

- involvement in senior management meetings;

- independent choice of scientific research topics;

- encouraging group work, free exchange of views between the manager and subordinates;

- cultivating organizational values that encourage innovative and active personnel behavior.

It is with the effective combination of direct and indirect motivation that causes high innovation activity of the staff, personnel involvement in making innovative decisions is connected with the successes of the Japanese and some Western industrial complexes in the development of advanced technologies.

Individual or group motivation depends on the goals set at the enterprise. Group motivation is faster, fewer resources are involved, but it is necessary to clearly distinguish different groups of workers according to the motivators, to develop systems of collective or individual motivators. Separation of groups is possible through questionnaires, psychological testing, assessing the level of work efficiency and more.

If the employee has a significant influence on the course of the innovation process, his psychological characteristics require a separate approach, and then individual motivation can be applied. This type of motivation allows us to formulate the motives and values of the employee more accurately.

Motivation for innovative solutions to issues that persist in the process of operating activities, development of innovative products, and the introduction of innovative marketing is possible without involving a significant amount of financial resources under the condition of effective management and implementation of advanced management and planning methods in the enterprise.

The assessment of the employee motivation of 
industrial enterprises should be performed after the implementation of all actions aimed at motivating and stimulating employees. The evaluation process should be based on evaluation criteria, their mathematical processing and interpretation of results. Evaluation criteria may be different in nature and substance. One of the most common approaches is that specialists determine changes in the financial indicators that characterize the state of the enterprise before and after motivation. This approach allows us to quantify the positive effects of increasing employee motivation. But the difficulty is in clearly distinguishing the positive effects derived from increased motivation from other positive factors that contributed to the growth of profits. That is, this approach allows us to determine the overall effect of the implementation of various measures that promote profit growth. An alternative approach to determining the level of motivation is to interview employees with further processing of the information received in order to determine their needs and motivation level. This approach allows us to obtain directly the necessary information from the objects of motivation and to determine the directions for improving the motivation policy.

\section{Construction of the model of the employee motivation process to innovation activity}

For the practical implementation of the proposed approach, it is necessary to determine a set of motivational needs, the level of satisfaction of which will be further evaluated. To assess the level of motivation, we adopted the Harrington Desirability Scale. Using this approach allows us, in the presence of a certain set of quantitative indicators, to evaluate the level of reasonableness by calculating a generalized desirability index D. The main motivational needs, the satisfaction of which should be assessed, in our opinion, include:

- level of wages;

- level of bonuses and allowances for well-done or additional work;

- adequacy of the amount of work to volume of incentives

- comfort of working conditions including moral microclimate;

- possibility of self-improvement;

- adequacy of penalties and fines for the level of damage involved;

- level of employee demand at the enterprise.

Employee surveys should only be conducted anonymously, with strict compliance with the rules for conducting this research and information processing. The employee should be warned about the need for a thorough and responsible approach to the questioning. To simplify the work with the function of desirability, the variation of the values of motivational needs (factors) will be considered for all factors in the range of definition [0.. 12], where zero is absolute dissatisfaction and twelve complete satisfaction of this need.

To translate the values of factors of influence (x) into the Harrington coded scale (y), we use the already developed approach. Let us assume that the relationship between the variables is linear and it is described by the equation:

$$
y(x)=a_{0}+a_{1} \times x,
$$

where $a_{0}$ is a free term of the linear equation; $a_{1}$ is the coefficient for the variable $x$.

By graphical comparison, it is determined that when the values of factors $x=3$, the value of the encoded argument $\mathrm{y}=0$ and the value of the function thus becomes $d=0.37$. When $x=6$, the value of the coded argument $y=2$ and the value of the function $d=0.873$. Thus it is possible to make a system of equations:

$$
\left\{\begin{array}{l}
a_{0}+a_{1} \times 3=0 \\
a_{0}+a_{1} \times 6=2
\end{array}\right\} \text {. }
$$

From (5.5) substitution we define that $\mathrm{a}_{0}=-2 ; \mathrm{a}_{1}$ $=0.667$. Thus, equation (4) for the above factors will take the form (Fig. 3):

$$
y(x)=-2+0,667 x \text {. }
$$

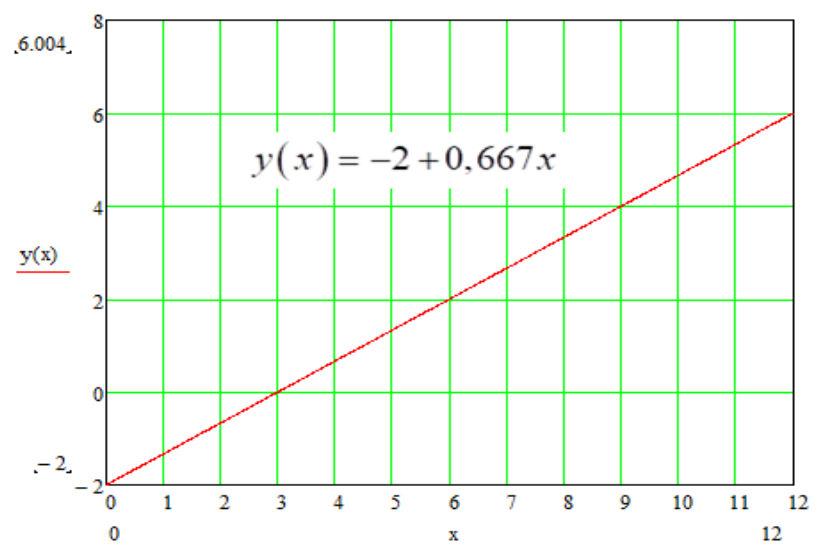


Figure 3: Graph of dependence of the values of the coded argument (y) of Harrington's desirability function on the values of the input factors (x)

Then the value of the desirability function for the factors will look like:

$$
d(x)=e^{\left(-e^{-(-2+0,667 x)}\right)}
$$

For practical use of the desirability function, there has been developed a table with meanings of ranges of values of motivational factors depending on their linguistic evaluation, Table 1.

Thus, in the survey, employees will use the values from Table 1 to evaluate the constituents of the motivation level.

Table 1. Range of the values of motivation factors, depending on their linguistic evaluation

\begin{tabular}{|l|l|l|l|l|l|}
\hline $\begin{array}{c}\text { Very } \\
\text { bad }\end{array}$ & $\begin{array}{l}\text { Unsatis- } \\
\text { factory }\end{array}$ & $\begin{array}{c}\text { Satisfac } \\
\text { tory }\end{array}$ & Good & $\begin{array}{c}\text { Very } \\
\text { good }\end{array}$ & $\begin{array}{c}\text { Ex- } \\
\text { cel- } \\
\text { lent }\end{array}$ \\
\hline $0-2,3$ & $2,4-3,0$ & $3,1-4,2$ & $\begin{array}{l}4,3- \\
5,3\end{array}$ & $\begin{array}{l}5,4- \\
6,9\end{array}$ & $7-12$ \\
\hline
\end{tabular}

Figure 4 shows the graph of the desirability function to estimate the level of employee motivation. Let us consider in more detail the proposed factors of influence on the motivation level of employees of an industrial enterprise.

The level of wages is determined by the base rate in accordance with the tariff grid of the position occupied by the employee, as well as the level of permanent bonuses provided by the management of the enterprise, depending on the employee's qualification, experience and productivity. The level of wages determines the general level of productivity in the work and the employee's usefulness for the enterprise and it is the basis for calculating the value of one-time incentives. Increasing or decreasing the level of wages can be done by transferring the employee to lower or higher positions, reducing the level of permanent bonuses.

As a result of well-done main amount of work, or additional work aimed at implementing the innovation strategy, the employee of the enterprise may be given temporary bonuses or lump sums, which also serve as a motivator for the employee's further actions beyond the minimum set by the job responsibilities.

The implementation of actions aimed at implementing the provisions of the innovation strategy requires the employee additional efforts, which should be directed to the development of new technologies, approaches, gaining new knowledge and skills, performing additional work of higher qualification level. The level of employee motivation depends on the adequacy and appropriateness of the promotion to the amount of additional work performed. It is especially important to consider the work involved in preparing the employee to implement innovative strategies. Employee's assessment of compliance with the levels of encouragement and accomplishment is one of the most important indicators of employee satisfaction, motivation.

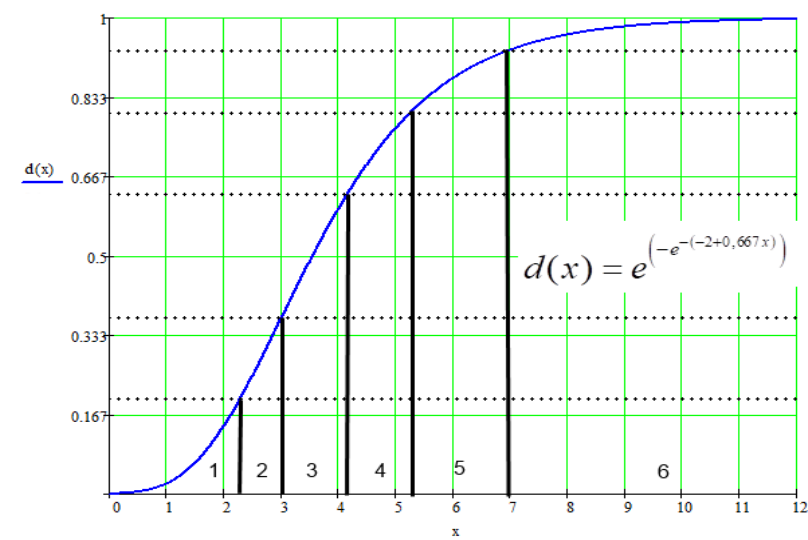

Figure 4: The graph of the Harrington desirability function for evaluating the motivation level of the enterprise's employees

where the zones of level of motivation are the following: 1 - "very bad"; 2 - "unsatisfactory"; 3 "satisfactory", 4 - "good", 5 - "very good", 6 "excellent"

The level of employee satisfaction depends directly on the comfort of working conditions, namely the set of parameters of the microclimatic conditions of the workplace, the convenience and adaptability of the tools, the equipment of the workplace in accordance with the tasks. Equally important is the maintenance of psychological comfort when the work of the employee is not accompanied by psychological pressure from colleagues or management.

Motivated workers need self-improvement, development to meet their ambitions or to meet the new challenges they face. The need for selfimprovement is a need for only a fraction of employees, but it is they who are the main driving force behind the implementation of innovative strategies. Promoting this cohort of employees in their desires for development is one of the goals of enterprise management. 
In addition to the encouragement and the creation of comfortable working conditions, each employee may be subject to penalties for certain misconduct and poor performance of work. Penalty discourages employees, reducing their desire to go beyond their usual responsibilities, but it is a necessary tool to encourage and control employees. The worst case of demotivation is excessive penalty, which is not proportionate or inadequate to the employee's misconduct. Such excessive penalties are significant demotivators and can completely destroy the employee's initiative.

Another important factor in assessing employee motivation is the demand at the enterprise. An employee who feels his need at the enterprise, the importance of his work in the total amount of work performed, will always be ready to do more than he is expected to do.

\section{Result and discussion}

In order to evaluate abovementioned factors by the employees, we offer to introduce a survey matrix, which is the basis for the questionnaires.

The gradation of the values of the generalized coefficient is as follows: [0.. 0.2$]$ is very bad; $\left(\begin{array}{ll}0.2 \ldots & 0.37\end{array}\right]$ - unsatisfactory; $(0.37 \ldots 0.63]$ satisfactory; $(0.64 \ldots 0.8]$ - good; $(0.8 \ldots 0.93]$ - very good; $(0.93 \ldots 1]$ - excellent.

To evaluate the above factors of motivation by employees, the survey matrix has been used, which is the basis for the questionnaires. In this matrix, the employees of the Ukrainian machine-building enterprises evaluated their satisfaction with material and moral factors.

Table 2 summarizes the results of the evaluation of the employees' motivation of a number of machinebuilding enterprises in Ukraine.

According to the results of the questionnaire survey of employees, it has been revealed that at different enterprises the employees evaluate the factors quite differently. Thus, at two enterprises, the level of wages and comfort of work have been assessed by employees as satisfactory, and at the third one, they have been assessed as unsatisfactory.

The results of the questionnaire survey revealed that the level of wages and comfort of work is rated by employees of the PJSC "Vinnytsia Plant Budmash" as satisfactory, the level of bonuses and allowances for additional work is rated as "very good". The correspondence of the value of incentives to the level of work is rated as "excellent"; the possibility of self-improvement and the adequacy of penalties and fines to the level of harm involved were rated as "unsatisfactory" and "very bad"

In accordance with the values of the input factors and formula (3), the value of the utility functions has been calculated and the value of the general indicator of the utility (motivation) of the employees to the implementation of innovative strategies has been determined. The analysis of Table 2 allows us to draw the following conclusions: all enterprises are motivated at the level of satisfactory and unsatisfactory assessment. This situation is because employees are dissatisfied with the level of wages, the comfort of working conditions and the level of adequacy of the penalties to the damages involved.

Table 2: Results of evaluation of the motivation level of employees of the enterprises to implementation of innovation with the help of the Harrington disirability function

\begin{tabular}{|c|c|c|c|c|c|c|}
\hline \multirow[t]{2}{*}{ Factors } & \multicolumn{3}{|c|}{$\begin{array}{r}\text { Values of } \\
\text { factors (x) }\end{array}$} & \multicolumn{3}{|c|}{$\begin{array}{l}\text { Values of the Harrington } \\
\text { desirability function d(x) }\end{array}$} \\
\hline & 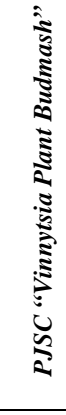 & 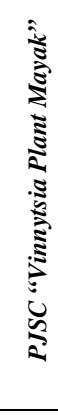 & 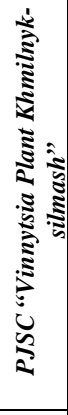 & 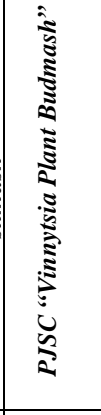 & 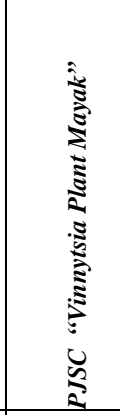 & 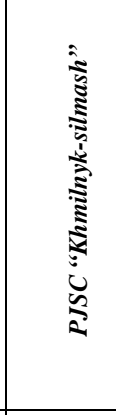 \\
\hline Level of wages & 4,1 & 3,2 & 1,2 & 0,61900 & 0,41718 & 0,03620 \\
\hline $\begin{array}{lr}\text { Level } & \text { of } \\
\text { bonuses and } \\
\text { allowances for } \\
\text { well-done or } \\
\text { additional work }\end{array}$ & 5,7 & 4,5 & 2,5 & 0,84791 & 0,69258 & 0,24797 \\
\hline $\begin{array}{l}\text { Adequacy of the } \\
\text { amount of work } \\
\text { to volume of } \\
\text { incentives }\end{array}$ & 7,2 & 2,5 & 3,5 & 0,94114 & 0,24797 & 0,48885 \\
\hline $\begin{array}{l}\text { Comfort of } \\
\text { working } \\
\text { conditions } \\
\text { including moral } \\
\text { microclimate }\end{array}$ & 3,8 & 1,5 & 3,6 & 0,55660 & 0,06608 & 0,51196 \\
\hline $\begin{array}{l}\text { Possibility of } \\
\text { self- } \\
\text { improvement }\end{array}$ & 2,7 & 2,8 & 2,0 & 0,29514 & 0,31932 & 0,14278 \\
\hline $\begin{array}{l}\text { Adequacy of } \\
\text { penalties and } \\
\text { fines for the } \\
\text { level of damage } \\
\text { involved }\end{array}$ & 2 & 3,8 & 3,3 & 0,14278 & 0,55660 & 0,44139 \\
\hline $\begin{array}{l}\text { Level of } \\
\text { employee } \\
\text { demand at the } \\
\text { enterprise }\end{array}$ & 4,5 & 5,5 & 3,6 & 0,69258 & 0,82818 & 0,51196 \\
\hline $\begin{array}{l}\text { Generalized desir } \\
\text { (motivation) }\end{array}$ & ili & 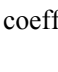 & ient & 0,50157 & 0,35365 & 0,25586 \\
\hline
\end{tabular}




\begin{tabular}{|c|c|c|c|}
\hline $\begin{array}{l}D=\sqrt[7]{d_{1} \times d_{2} \times \ldots \times d_{7}} \\
\text { Linguistic assessment }\end{array}$ & 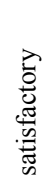 & 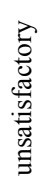 & 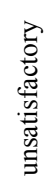 \\
\hline
\end{tabular}

Therefore, in order to increase the motivation level of the management of the enterprise, it is necessary to concentrate efforts. First of all, on reducing the amount of penalties and bringing them to an adequate level and to low-cost measures to improve the working conditions and access of employees to self-realization - improvement of temperature regimes, reduction of the level of social tension in the team, collective visits of exhibitions and symposia, free access to the Internet and specialized literature.

Measures aimed at increasing wages, bonuses and allowances require a considerable expense of the enterprise, which is not always possible; the level of possible growth of these payments should be determined only after a detailed assessment of the financial state of the enterprise and prospective revenues from the implementation of innovative strategies.

\section{Conclusion}

The proposed approach allows us with the help of anonymous questionnaire of enterprise's employees to determine the general level of employee motivation and ways to improve it, depending on the level of individual components desirability functions. First of all, efforts should be directed to the implementation of cost-free and lowcost measures to increase motivation and after the implementation of these directions to make changes in the financial support of employees.

Linguistic assessment of the level of employee motivation is further used in the mathematical model of decision support for the choice of sources of financing innovative strategies of industrial enterprises, while determining the values of the efficiency index of financial support for innovation activity.

Thus, effective motivation of employees will increase the efficiency of innovation activity, which will ultimately lead to an increase in the level of profitability and competitiveness of enterprises. Domestic enterprises should actively introduce incentive measures of indirect action of tangible and intangible nature; use the methods of the Japanese management system.

The proposed approach has some limitations. The calculation was made for machine-building enterprises of Ukraine, so the obtained results may not be quite correct for assessing the employees' motivation of enterprises of other industries or other countries.

The result of further research should be the formation of a universal system of factors that influence employees' motivation to innovation activity in other sectors of the economy

\section{References:}

[1] V. V. Stadnyk System support of motivation of innovative development of business structures. Khmelnitsky: KhNU, 2009.

[2] V. V. Bokovets Development of motivational mechanisms - acceleration of innovation activity of enterprises, Economy and society 9, 2017, pp. 395-398. http://economyandsociety.in.ua.

[3] A. O.Klymchuk, A.N.Mikhailov The motivation and stimulation of personnel in effective enterprise management and innovation activity improving. Marketing and Management of Innovations, 1, 2018, pp. 218234. http://doi.org/10.21272/mmi.2018.1-16.

[4] R. M. Yerkes, J. D. Dodson The Relation of Strength of Stimulus to Rapidity of HabitFormation". Journal of Comparative Neurology and Psychology, 18, 1980, pp. 459-482. https://doi.org/10.1002/cne.920180503.

[5] S. M.Ilyashenko Innovations in marketing and management. Sumy: Papyrus, 2013.

[6] D. C. McClelland. Human motivation. Cambridge University Press, 1987.

[7] I. Masaaki Kaizen: The Key To Japan's Competitive Success. McGraw-Hill Education, 1986

[8] A. H. Maslow Motivation and Personality. Addison-Wesley Educational Publishers Inc., 1987.

[9] C. Alderfer Existence, Relatedness and Growth. New York: Free Press, 1972.

[10] D. McGregor The Human Side of Enterprise. New York: McGraw-Hill, 1960.

[11] G. L. Verbitskaya Motivation of personnel at domestic industrial enterprises. Bulletin of Lviv Polytechnic National University. Management and entrepreneurship in Ukraine: stages of development and development problems, 727, 2012, pp. 10-15.

[12] V. H. Vroom Work and Motivation. New York: Wiley, 1964.

[13] D. Carnegie How to Develop Self Confidence and Improve Public Speaking. New York: Pocket books, 1991.

[14] N. Hussein, A. Mohamad, F. Noordin, N.A. Ishak Learning organization and its effect on 
organizational performance and organizational innovativeness: a proposed framework for Malaysian Public Institutions of Higher Education', Procedia-Social and Behavioral Sciences, May, Vol. 130, 2014, pp. $299-304$. https://doi.org/10.1016/j.sbspro.2014.04.035.

[15] I. Gontareva, B. Maryna, V. Babenko, I. Perevozova, A. Mokhnenko. Identification of efficiency factors for control over information and communication provision of sustainable development in higher education institutions. WSEAS Transactions on Environment and Development. Vol. 15, 2019, pp. 593-604.

[16] M. Goepel, K. Hölzle, D.Knyphausen-Aufseß Individuals' innovation response behaviour: a framework of antecedents and opportunities for future research, Creativity and Innovation Management, Vol. 21, No. 4, 2012, pp. 412426. https://doi.org/10.1111/caim. 12000

[17] V. Babenko. Formalization of the Model of Management of the Technological Innovations. CEUR Workshop Proceedings, vol. 2393, 2019, pp. 595-602. Online, http://ceur-ws.org/Vol-2393/. http://ceurws.org/Vol-2393/paper_431.pdf

[18] R.Aalbers, W. Dolfsma, O. Koppius Individual connectedness in innovation networks: on the role of individual motivation, Research Policy, Vol. 42, No. 3, 2013, pp.624-634, https://doi.org/10.1016/j.respol.2012.10.007

[19] V. Lendela, D.Moravč́́kováa, M. Latkaa. Organizing Innovation Activities in company Procedia Engineering, 192, 2017, pp. $615-$ 620, doi: 10.1016/j.proeng.2017.06.106

[20] A. Kallingal, M. Rajarathinam Employee motivation to innovate and resources management: the mediating role of organisational commitment. International Journal of Management Concepts and Philosophy, Vol. 9, No. 3, 2016, pp. 185 199.

http://doi.org/10.1504/IJMCP.2016.078307

[21] J. Craig Wallace, Marcus M. Butts, Paul D. Johnson, Flannery G. Stevens. Mickey B. Smith. A Multilevel Model of Employee Innovation: Understanding the Effects of Regulatory Focus Thriving and Employee Involvement Climate. Journal of Management, Vol. 42, Iss. 4, 2013, pp. $982-$ 1004.

https://doi.org/10.1177/0149206313506462

[22] E. A. Saether. Motivational antecedents to high-tech R\&D employees' innovative work behavior: Self-determined motivation, person-organization fit, organization support of creativity, and pay justice. The Journal of High Technology Management Research, 30, 2019, https://doi.org/10.1016/j.hitech.2019.10 $\underline{0350}$

[23] E. C. Harrington. The desirability function. Industrial Quality Control, vol. 21, no. 10, 1965, pp. 494-498.

[24] P. M. Hryhoruk. A model of complex integrated evaluation of marketing decisions effectiveness. Actual problems of economic cybernetics: the collective monograph / ed. A. Yu. Chubukova, NV Geseleva. Kiev: Stylos, 2014.

[25] V. V. Kruglov. Fuzzy logic and artificial neural networks. Moscow: Fizmatlit, 2001.

[26] M. P. Voynarenko, V. V. Dzhedzhula, I. Yu. Yepifanova. Modelling the process of making decisions on sources of financing of innovation activity. Economic Annals-XXI, 160 (7-8), 2016, pp. 126-129

[27] V. Dzhedzhula, I. Yepifanova. Use of apparatus of hybrid neural networks for evaluation of an intellectual component of the energy-saving policy of the enterprise. Baltic Journal of Economic Studies, Vol. 4, № 1, 2018, pp. 126-130. https://doi.org/10.30525/2256-0742/2018-4$1-126-130$

[28] K. Goffin, R. Mitchell. Innovation Management: Strategy and Implementation using the Pentathlon Framework. Macmillan Education UK, 2010.

[29] P. Koudelková, F. Milichovský. Successful innovation by motivation. Business: Theory and Practice, 16(3), 2015, pp. 223-230.

[30] Innovative Development Strategy of Ukraine for 2010-2020 in the Context of Globalization Challenges [Ed. : G. A. Androschuk, I. B. Zhilyaev, B. G. Chizhevsky, M. M. Shevchenko]. K.: Parliamentary View, 2009. 